\title{
FREI BETTO E AS CARTAS DA PRISÃO: a edificação de um projeto memorialístico
}

Bruno Dias Santos*

\begin{abstract}
RESUMO: O monopólio da memória da ditadura militar brasileira é disputado ferozmente por militantes de esquerda e militares desde a deposição do presidente João Goulart em 1964. No entanto, já se avalia que essa batalha se estende ao interior desses grupos (por não serem monolíticos). Dessa forma, a análise das cartas de frei Betto busca compreender o trabalho de edificação de seu projeto memorialístico sobre o período, de maneira a ressaltar como a memória foi utilizada pelo autor para se posicionar diante dos conflitos que marcaram seu contexto de produção. Pretende-se rastrear as estratégias discursivas desenvolvidas pelo escritor para reivindicar o estatuto de verdade à sua narrativa perante as versões dos adversários políticos e dos companheiros de militância.

PALAVRAS-CHAVE: Memória; Ditadura militar; Frei Betto; Cartas.
\end{abstract}

\section{Frei Betto and the prison letters: the construction of a memorialistic project}

ABSTRACT: The monopoly of the Brazilian civil-military dictatorship memory is fiercely disputed by left and military, since the disposal of the president João Goulart in 1964. The battle, already, extends to the inside of this groups (by not being monolitics). In this way, the analysis of the Frei Betto's letters seeks to understand the work of his memorialistic project about the period, in order to emphasize how the memory used by the author to stand in the face of conflicts that marked his context of production. It's pretended to trace the discursive strategies developed by the writer to claim the status of truth to his narrative in front of the versions of political opponents and companies of militancy.

KEYWORDS: Memory; Civil-military dictatorship; Frei Betto; Letters.

\section{Fraile Betto y las cartas de la prisión: la edificación de un proyecto memorialístico}

RESUMEN: El monopolio de la memoria de la dictadura militar brasileña es disputada ferozmente por militantes de la izquierda y militares desde la destitución del presidente João Goulart en 1964. Sin embargo, se evalúa que esa batalla se extiende al interior de esos grupos ( por no ser monolíticos). De esta forma, el análisis de las cartas del fraile Betto busca comprender el trabajo de edificación de su proyecto memorialista sobre el período, de este modo resalta como la memoria fue utilizada por el autor para posicionarse delante de los conflictos que marcaron su contexto de producción. Se pretende rastrear las estrategias discursivas desarrolladas por el escritor para revindicar el estatuto de verdad de su narrativa ante las versiones de los adversarios políticos y de los compañeros de militancia.

PALABRAS- CLAVES: Memoria; Dictadura militar; Fraile Betto; Cartas.

\footnotetext{
* Doutorando em História pela Universidade Estadual Paulista “Júlio de Mesquita Filho" (UNESP) - Faculdade de Ciências e Letras de Assis-SP. Possui mestrado e graduação em História pela mesma instituição. Suas pesquisas concentram-se na História do Brasil Republicano, com ênfase na ditadura militar (1964-1985). Contato: Av. Dom Antônio, 2100, Parque Universitário, CEP: 19806-900, Assis-SP, Brasil. E-mail: bruno.dias.santos@hotmail.com
} 


\section{INTRODUÇÃO}

Passados três anos da rememoração do cinquentenário do golpe civil-militar que depôs o presidente João Goulart e inaugurou a ditadura liderada pelos militares com o apoio de setores civis, mais uma vez a memória sobre o período é evocada pelo calendário. No próximo ano, será a vez do AI-5, Ato Institucional decretado a 13 de dezembro de 1968 pelo general Costa e Silva que suspendeu direitos básicos da população brasileira, como o de habeas corpus, além, de institucionalizar arbitrariedades que desde abril de 1964 estavam sendo praticadas.

No entanto, a iniciativa da publicação de livros, realização de eventos temáticos e exposições não pode ser considerada como produto, exclusivamente, das casualidades de calendário. A memória é, antes de tudo, segundo o historiador francês Michel Pollak “colorida pelo presente". Dessa maneira, podemos dizer que no presente persiste uma demanda pela sua construção a respeito do período.

Já é bastante frequente entre os historiadores o uso de memórias pessoais ou coletivas como fontes para a produção historiográfica sobre a ditadura militar no Brasil (1964-1985). Entretanto, nos últimos anos cada vez mais "rememorar" tem sido compreendido como um ato histórico, que inclusive tem influência sobre a produção acadêmica. Justamente por sua complexa relação com o universo político e cultural do país, a memória não pode ser tomada apenas como fonte para o trabalho do historiador, mas, também como objeto de estudo para análise de discursos produzidos sobre ele.

A memória se insere na História, cultural e política do país como representação erigida em uma sucessão temporal e reforçada por discursos que influenciam profundamente as ações no presente; portanto é comum que ela seja constantemente reconstruída, como armas que são constantemente afiadas, para enfrentar novas batalhas. Neste caso, a luta é pelo status de verdade. Independente da consciência ou intencionalidade do autor, todo aquele que rememora e narra suas lembranças estabelece um desejo de verdade acompanhado por uma vontade de poder. (FOUCAULT, 2015, p.53).

O contato com a obra de frei Betto evidencia, inicialmente, a intensa disputa em torno da memória. A mais conhecida, obviamente, opõe ex-militantes de esquerda e membros das forças armadas; no entanto, uma leitura mais atenta das publicações sobre o assunto faz emergir as divergências no interior desses agrupamentos. Como exemplo, pode-se citar o debate entre frei Betto e Jacob Gorender sobre a morte de Carlos Marighella: 
Jacob Gorender, em seu livro Combate nas Trevas, afirma que "nos cárceres-aqui, o testemunho é meu - era generalizada a convicção dos presos políticos acerca da responsabilidade de Fernando e Yves na tragédia da Alameda Casa Branca" (p.197). $E$ acrescenta mais adiante ' $O$ meu silêncio de historiador significaria conivência com a versão divulgada por Frei Betto, em curso no Brasil e no exterior. Silêncio inadmissível diante do compromisso que o historiador tem com a verdade (...) Frei Betto preferiu a meia verdade, o que é igual à meia falsidade". Sua versão reconhece a que sobe tortura, Fernando e Yves (hoje ex-frade) denunciaram o dispositivo de ligação com o líder da ALN. Veja-se bem: não sou o primeiro na área de trazer isto a público. Precedeu-me Frei Betto. Mas sua versão acumula invencionices...' (PP.198). Não foram os frades que procuraram a polícia. A polícia prendeu-os e torturou-os. Gorender isenta Paulo de Tarso Venceslau de ter delatado os frades (pp.198-199) e não esclarece como a repressão soube que um grupo de dominicanos servia de apoio logístico a Marighela. E o que é mais estranho: um historiador jamais despreza uma fonte viva, ainda mais se os dois residem no mesmo país. Gorender nunca demonstrou interesse em entrevistar Ivo e Fernando, mas teve o cuidado de ouvir a versão de Paulo de Tarso Venceslau, como se o visceral anticlericalismo incutido em alguns comunistas brasileiros tivesse ainda o peso capaz de prejudicar a objetividade de quem pretende encarar a história pelo método científico. O compromisso com a verdade deve estar acima dos preconceitos (BETTO, 2009, p. 257).

Assim sendo, emerge o questionamento sobre as razões que fizeram com que determinadas versões dos acontecimentos se tornassem hegemônicas no senso comum. $\mathrm{Ou}$ seja, quais são os fatores que transformaram a visão de alguns autores em uma espécie de "memória oficial", convencionalmente denominada como a "memória dos vencidos", enquanto, outros escritores de igual renome não exerceram a mesma influência, sendo alguns até mesmo esquecidos.

Neste caso específico, a solidificação dessa memória dominante resultou de um processo de construção narrativa baseado em estratégias que o dotassem de veracidade somando-se às manifestações de outros gêneros, como o estabelecimento de memoriais, exposições, produções fílmicas e etc. Assim, essa concepção individual se reforça ao mesmo tempo em que é robustecida por um empreendimento coletivo. Apesar das divergências, a maioria das obras que o integram alimentam uma versão básica da história, o que se pretende analisar nesta pesquisa.

No caso da produção memorialística de frei Betto, observa-se claramente a realização deliberada de um, por assim dizer, projeto editorial, seja pela quantidade de obras ou pela periodicidade com que ele produz sua reelaboração. Essa revisão das versões, em que uns aspectos se perdem e outros são acrescentados, não deve ser vista apenas por uma perspectiva psicológica, ou como produto do inconsciente ou do distanciamento temporal dos acontecimentos. 


\section{História e memória}

O interesse dos historiadores pela memória pode ser questionado, inicialmente, devido à certeza, apregoada pelo senso comum, de que ela é uma faculdade absolutamente individual, ainda que grande parte das lembranças que acreditamos possuir possa ser dividida com outras pessoas que também presenciaram os episódios sobre as quais estas versam. Contudo, o estudo mais apurado do fenômeno revela seu caráter coletivo e de que maneira ele se apresenta como uma fonte/objeto complexa e riquíssima para a pesquisa histórica.

Maurice Halbwachs, autor da célebre obra "A memória coletiva”, já apontava que o hábito de "atribuirmos a nós mesmos, como se apenas em nós se originassem, as ideias, reflexões, sentimentos e emoções" é apenas uma "ilusão natural" que faz passar despercebidas suas raízes sociais. Assim, é importante que se perceba que aquilo que consideramos como "a memória individual" é, antes de tudo, "um ponto de vista sobre a memória coletiva, que (...) muda segundo o lugar que ali ocupo e que esse mesmo lugar muda segundo as relações que mantenho com outros ambientes" (HALBWACHS, 2003, p.64-69). Desta forma:

À medida que cedemos sem resistência a uma sugestão externa, acreditamos pensar e sentir livremente. É assim que em geral a maioria das influências sociais a que obedecemos permanece desapercebida por nós. (HALBWACHS, 2003, p. 65)

O sociólogo francês insiste que mesmo que testemunhemos um acontecimento, fisicamente solitários, nossa percepção e, por conseguinte, nossa memória é cunhada a partir dos grupos aos quais pertençamos (HALBWACHS, 2003, p.30).

Em outras palavras, existe uma lógica da percepção que se impõe ao grupo e que o ajuda a compreender e a combinar todas as noções que lhe chegam do mundo exterior. (...) cada vez que percebemos, nós nos conformamos a essa lógica; ou seja, lemos os objetos segundo essas leis que a sociedade nos ensina e nos impõe (HALBWACHS, 2003, p.61).

Contudo, mesmo convencidos de que a memória detém um potencial aglutinador, não se pode negar seu aspecto coercitivo.

Embora reconheça a importância da contribuição Halbwachs, Pollak critica sua abordagem por enfatizar "funções positivas" desempenhadas por essa memória como a coesão social e a criação de uma "comunidade afetiva". O autor salienta que essa constatação não pode impedir que o historiador enxergue a violência simbólica que sua versão dominante exerce sobre determinadas minorias, nem mesmo o "caráter destruidor, unificador e opressor" de seu processo de solidificação, o que só se evidencia em momentos conflituosos em que os 
grupos subterrâneos rompem o silêncio e buscam a sua contestação (POLLAK, 1989, p. 1-2).

Em dois artigos já célebres, "Memória, Esquecimento e Silêncio" e a "Memória e Identidade Social", o autor desenvolve um debate fundamental sobre as funções sociais que a memória exerce e os caminhos para a sua análise como objeto da pesquisa histórica.

No primeiro, Pollak desenvolve o conceito "memória enquadrada", em contraposição ao de "memória coletiva", defendido pelo sociólogo francês Maurice Halbwachs, além de apresentar metodologias para a sua identificação e análise.

Praticando a História Oral junto a grupos que carregam profundos traumas da Segunda Guerra Mundial (1939-1945) como deportados, sobreviventes do holocausto ou soldados alsacianos e lorenos compulsoriamente recrutados, Pollak demonstra que a memória, seja ela oficial ou "subterrânea", juntamente com o esquecimento e o silêncio é produto de um mesmo trabalho de "enquadramento" (POLLAK, 1989, p. 9). Assim, o autor procura ressaltar que sua aplicação como objeto para a pesquisa histórica, inicialmente, dispõe de dois caminhos metodológicos possíveis: o trabalho de rastreamento, registro (através da História Oral) e análise das "memórias subterrâneas"; assim como, aquele que busca compreender o processo de construção e solidificação das versões englobantes.

$\mathrm{Na}$ visão do historiador, duas funções se destacam como principais entre as tantas que a memória pode desempenhar. São elas: a criação/manutenção da identidade e o estabelecimento de fronteiras sociais capazes de manter a coesão de um grupo. No entanto, a sua execução não se dá de maneira automática. É preciso o desenvolvimento de um trabalho de enquadramento que garanta a essa narrativa, credibilidade e coerência. Ainda que, para alcançar esse objetivo, seja necessário condenar ao silêncio e ao constrangimento os portadores de uma reminiscência que não se adeque a ela.

Levando em consideração esses apontamentos, este trabalho se cumpriria, basicamente, em duas etapas. A primeira seria a constante reinterpretação do passado à luz das disputas do presente; em seguida, o reforço de um quadro de pontos de referência que permita ao grupo se identificar com aquela versão, e por consequência dotá-la de aderência social. Para o implemento desse enquadramento é necessária a utilização de uma série de instrumentos. Entre os mais destacados, Pollak apresenta os historiadores oficiais de determinados grupos que assumem a função de "guardiões da verdade", ou seja, da narrativa que o grupo deseja que seja mantida; os espaços de memória, como monumentos museus e bibliotecas; e, por fim, a produção cultural, no caso, o cinema.

O que se destaca na análise de todo esse processo é a visualização de uma característica fundamental para que se tome a memória como objeto: sua seletividade. Isto é, 
aquilo que é registrado ou que se tenta esquecer atende à demanda "do momento em que ela é articulada, em que ela está sendo expressa". Segundo Pollak, "as preocupações do momento constituem um elemento de estruturação da memória" (POLLAK, 1992, p.204). Essa característica é reforçada por Pierre Nora ao afirmar que ela, por ser viva e dinâmica, "está em permanente evolução, aberta a dialética da lembrança e do esquecimento, inconsciente de suas deformações sucessivas, vulnerável a todos os usos e manipulações, susceptível de longas latências e de repentinas revitalizações" (NORA, 1993, p. 9).

Deste modo, pode-se afirmar que o processo de construção da narrativa dominante não se realiza de maneira tranquila, pelo contrário: "A memória e a identidade são valores disputados em conflitos sociais e intergrupais, e particularmente em conflitos que opõem grupos políticos diversos" (POLLAK, 1992, p. 205).

Em sua obra "História e Memória", Le Goff ressalta inicialmente que "a memória como propriedade de conservar certas informações, remete-nos em primeiro lugar a um conjunto de funções psíquicas, graças às quais o homem pode atualizar impressões ou informações passadas, ou que ele representa como passadas". Através de uma instigante reflexão sobre o desenvolvimento memorialístico e mnemotécnico, da transmissão oral à imprensa contemporânea, o autor salienta que apesar de seu papel essencial na busca humana pela construção da identidade “a memória (...) é também um instrumento e um objeto de poder". (LE GOFF, 1990, p. 476). Assim:

A memória coletiva foi posta em jogo de forma importante na luta das forças sociais pelo poder. Tornarem-se senhores da memória e do esquecimento é uma das grandes preocupações das classes, dos grupos, dos indivíduos que dominaram e dominam as sociedades históricas. Os esquecimentos e os silêncios da história são reveladores desses mecanismos de manipulação da memória coletiva (LE GOFF, 1990, p. 426).

Partindo da mesma convicção de Le Goff sobre seu caráter político, observa-se que não basta lembrar e narrar o passado. Esta empreita requer que aqueles que entram em contato com ela acreditem na sua veracidade.

Diante das considerações de Le Goff e Pollak acerca do caráter conflituoso de sua construção em torno do status de verdade, inclusive entre os detentores de uma memória subalterna ${ }^{1}$, tomamos como referências teóricas as considerações do filósofo francês Michael Foucault sobre a relação Saber/Poder.

De acordo com a perspectiva de Foucault, é necessário "ver historicamente como se produz efeitos de verdade no interior dos discursos que não são em si verdadeiros nem falsos" (FOUCAULT, 2015, p. 44). Aplicado à análise das cartas de frei Betto, isso significa analisar 
de que maneira frei Betto reivindica esse estatuto para a versão que construiu sobre a ditadura militar no Brasil.

Segundo Foucault, existe um "combate pela verdade":

O importante, creio, é que a verdade não existe fora do poder ou sem poder (...). A verdade é deste mundo; ela é produzida nele graças a múltiplas coerções e nele produz efeitos regulamentados de poder. Cada sociedade tem seu regime de verdade, sua "política geral" de verdade: isto é, os tipos de discurso que ela acolhe e faz funcionar como verdadeiros; os mecanismos e as instâncias que permitem distinguir os enunciados verdadeiros dos falsos, a maneira como se sanciona uns e outros; as técnicas e procedimentos que são valorizados para a obtenção da verdade; o estatuto daqueles que têm o encargo de dizer o que funciona como verdadeiro (FOUCAULT, 2015, p.49).

No caso específico das cartas da prisão de frei Betto - selecionadas como fonte para a realização da presente reflexão - que versam sobre a trajetória do próprio autor e, assim, o apresentam como personagem da própria narrativa é necessária uma atenção redobrada aos riscos do que o sociólogo francês Pierre Bourdieu denomina "Ilusão biográfica".

Esse alerta remete ao risco de que através da investigação biográfica o historiador reproduza uma concepção linear da história, coerentemente dirigida, com um escopo preestabelecido. Segundo o autor, essa "coerência orientada para uma finalidade" se estabelece no relato sobre a própria vida como uma ilusão retórica da qual o pesquisador deve esquivar-se, sem, no entanto, cair em um relativismo que impossibilite a análise da relação existente entre cada posição ocupada pelo sujeito em seu deslocamento social. (BOURDIEU, 2000, P.190).

A reflexão do autor sobre “A Ilusão Biográfica” é uma referência indispensável para o ofício de todo historiador. Entretanto, observamos que no caso da investigação sobre a construção da memória, mais do que uma "ilusão", esse "fio condutor", qualificado por Pollak como "trabalho de reconstrução de si mesmo" (POLLAK, 1989, p.13), que dota de sentido o relato autobiográfico é um instrumento de persuasão que corrobora a perspectiva de análise aqui desenvolvida. Assim, o que se busca é rastrear as estratégias utilizadas pelo autor para estabelecer um sentido maior a sua trajetória, e por consequência, angariar maior legitimidade e aderência.

\section{Experiências com a construção da memória sobre a ditadura militar no Brasil (1964-1985)}

O papel central que a memória tem exercido no processo de consolidação da democracia no Brasil após o fim do regime militar é consenso entre os historiadores. Esta é uma certeza que se torna mais instigante à medida que o mercado editorial apresenta 
periodicamente uma infinidade de títulos dispostos a perpetuar ou reeditar os relatos de exmilitantes de esquerda ou integrantes da luta armada, assim como, os recentes sinais de que alguns militares envolvidos diretamente no processo histórico estariam dispostos a uma reavaliação das posições adotadas para a sua disputa.

Certamente, o simples e superficial "passar de olhos" pelos empreendimentos de militantes e militares relacionados à memória, os primeiros empenhados em "lembrar", e parte do segundo grupo clamando pelo "esquecimento", ou ao menos pelo "silêncio", leva o leitor a perceber que as duas faces dessa mesma moeda têm um valor estratégico no presente, do qual as personagens em questão não estão dispostas a abrirem mão.

A leitura da historiografia produzida sobre esse processo histórico de construção da memória evidencia algumas de suas características que não podem ser negligenciadas pelo historiador; por exemplo, o seu caráter seletivo, legitimador do presente, seu caráter representativo de uma identidade social, seu caráter coletivo e a historicidade de sua construção. Todos esses elementos se baseiam na reflexão teórica dos autores discutidos na seção anterior. Nesta, convém abordar algumas possibilidades e limites observados nas experiências já realizadas.

Possuidora de uma vasta experiência e de diversas publicações sobre a construção da memória da ditadura militar brasileira, a historiadora Denise Rollemberg desenvolve junto ao Núcleo de Estudos Contemporâneas do Departamento de História da Universidade Federal Fluminense um importante trabalho de pesquisa sobre as biografias e autobiografias de militantes de esquerda.

Dois artigos em especial apresentam as contribuições do trabalho de Rollemberg para discussão sobre a construção das narrativas sobre o período: “As trincheiras da memória. A associação brasileira de Imprensa e a ditadura (1964-1974)" e "Esquecimento das memórias".

No primeiro, a historiadora analisa o caso da Associação Brasileira de Imprensa. Rollemberg apresenta o livro A trincheira da liberdade. A história da ABI, publicado em 1985 pelo jornalista e conselheiro, Edmar Morel, como o legítimo representante da memória coletiva que se construiu, no período de redemocratização, sobre a instituição. Esta seria caracterizada pelo seu maniqueísmo que teria diluído a diversidade e até mesmo a ambivalência das posições assumidas pela ABI no período. (ROLLEMBERG, 2010, p.105).

Segundo a historiadora, o próprio título do livro revela a intenção do autor: apresentar a instituição como uma daquelas que com mais vigor resistiu à ditadura violenta que os militares impuseram à sociedade brasileira. "Subentende, até pela metáfora trincheira, que a 
luta da instituição foi de enfrentamento em campo claramente definido em relação a outro campo, como numa guerra, opostos pela guerra" (ROLLEMBERG, 2010, p.105).

Através da análise das atas das reuniões ordinárias e extraordinárias do conselho administrativo e de seus boletins, a pesquisadora procura demonstrar que as discussões da associação apresentam as ambivalências em relação ao regime que ela procura definir através do conceito penser-double desenvolvido pelo historiador francês Pierre Laborie para abordar o regime de Vichy (1940-1944) na história francesa (ROLLEMBERG, 2010, p.130).

Rollemberg afirma a existência de uma zona cinzenta, o que comprovaria que as posições expressas nas atas não obedeciam ao comportamento austero de combate à ditadura, contradizendo frontalmente o caráter monolítico e inexpugnável da $\mathrm{ABI}$ na luta contra o regime, como proposto por Morel em seu livro.

Rollemberg reafirma a interpretação de Daniel Aarão Reis, segundo a qual, a memória construída sobre a ditadura militar teve como pano de fundo o processo de distensão política e transição para a democracia; e a conciliação como protagonista (AARÃO REIS, 1997, p.37). Cintando o historiador, ela afirma que "o ano de 1979, marco no longo processo, expressa o sentido de conciliação no qual a transição da ditadura para a democracia estruturou-se". Complementarmente, se a conciliação influencia a produção da memória, esta por sua vez é uma arma poderosa na luta para construí-la.

A pesquisadora ressalta que até mesmo a nomenclatura que se tornou corrente reafirma a versão que se tornou dominante. A ditadura teria sido imposta pelos militares; ela seria exclusivamente militar; suas práticas desumanas teriam sido cometidas longe dos olhos da opinião pública nos famigerados porões, em anos de chumbo. Dessa forma, a interpretação que se consagrou como oficial busca: "Enfatizar o papel dos movimentos sociais de oposição e/ou de resistência democrática" (ROLLEMBERG, 2010, p.100).

A historiadora ainda ressalta que esta versão não se tornou dominante por que foi imposta, mas porque atendia melhor as demandas da sociedade naquele período. Com sua análise, ela procura ainda demonstrar que a versão da memória, em que a resistência foi a tônica, é uma construção a posteriori.

Corroborando essa interpretação, em "Esquecimento das memórias", como o próprio título sugere, a autora analisa a outra face da moeda: aquilo que não se deseja lembrar nem narrar.

$\mathrm{O}$ artigo, claramente, se propõe a fazer um balanço da experiência de Rollemberg com as memórias publicadas sobre o período, especialmente as dos militantes de esquerda. Ao abordar a, já clássica, dicotomia entre a narrativa dos grupos de esquerda e o esquecimento 
(ou silêncio) dos militares, a autora relaciona duas importantes constatações; a hegemonia que o livro de Fernando Gabeira, O que é isso companheiro?, exerce no senso comum sobre a luta armada, ratificando a interpretação de Daniel Arão Reis, e o interesse do mercado editorial em publicar o fluxo considerável das lembranças de ex-militantes de luta armada.

Rollemberg observa que a ideia de que os vencidos no enfrentamento das armas acabaram vencendo no campo da memória esconde especificidades mais profundas neste processo histórico que precisam ser elucidadas. Entre os vencedores existiriam, em sua concepção, também aqueles que foram derrotados; ou seja, muitas dessas narrativas que chegaram ao mercado editorial não conseguiram até o presente momento serem incorporadas à memória coletiva sobre o quê foi a luta armada sendo até mesmo esquecidas. E a autora se questiona: "Não foi esta "depuração" que tornou possível o fato tão raro na história, de os vencidos vencerem a memória dos vencedores?” (ROLLEMBERG, 2006, p.84). Sua resposta é afirmativa.

A autora atribui esse processo primeiramente ao desejo de conciliação que marcara a transição para o regime democrático, à necessidade dos ex-militantes de justificarem suas escolhas no passado e, por fim, à dificuldade que a esquerda teria em reconhecer a relação que a sociedade tinha com a ditadura; esta seria fruto da maneira como os grupos idealizavam essa relação. (ROLLEMBERG, 2006, p.85).

Outro ponto importante ressaltado pela autora para o sucesso da versão de Gabeira é a necessidade que a própria sociedade tinha de esquecer o apoio à ditadura. Assim, construiu-se a versão de que todos resistiram bravamente à imposição dos militares no poder.

A historiadora conclui que ao se escolher o que se quer lembrar também seleciona-se o que será esquecido. Ironicamente, segundo Rollemberg, a construção da memória da esquerda colabora com o que a sociedade e os militares preferem manter no esquecimento. (ROLLEMBERG, 2006, p.90).

A perspectiva de análise e as conclusões de Rollemberg sem dúvida constituem uma contribuição importantíssima ao debate sobre a memória e a História do regime militar brasileiro; principalmente, a identificação de uma aspiração histórica pela conciliação, e até pelo esquecimento de alguns aspectos, que em sua visão foi a tónica desse processo no período de transição para o regime democrático (ROLLEMBERG, 2006, p.131). No entanto, é preciso observá-la com cuidado.

É tentadora a possibilidade de se considerar como inevitável a hegemonia exercida pelo livro de Fernando Gabeira $O$ que é isso companheiro?; ou seja, acreditar que seria praticamente impossível que outra versão fosse incorporada pela memória coletiva, devido ao 
encaixe quase perfeito entre a versão apresentada no livro e os aspectos que a sociedade desejava esquecer e lembrar.

No entanto, faz-se necessário observar que a resposta satisfatória dada pela versão de Gabeira, assim como de outros militantes, aos anseios da sociedade em relação ao que precisaria ser lembrado e esquecido devem-se as suas escolhas, mesmo que algumas tenham sido inconscientes. É preciso ponderar que a seletividade da memória se guia pelo presente; neste aspecto, no caso dos grupos de esquerda, o que se observa como mais preponderante é o desejo de dotar de legitimidade o que foi feito no passado.

Assim, construir uma narrativa em que só os grupos de esquerda, e principalmente de luta armada, fossem vistos como aqueles que resistiram à ditadura, enquanto grande parte da sociedade era conivente com as práticas do regime, poderia resultar em um isolamento da esquerda e uma segunda derrota, agora no campo de batalha pela memória. Mas se ao contrário, a versão que se escreveu afirma que toda a sociedade brasileira resistiu como pode à ditadura imposta pelos militares, aqueles que levaram essa resistência às últimas consequências, foram elevados ao panteão de heróis nacionais (ROLLEMBERG, 2007, p. 15); certamente, isso não se deve a um saber constituído despropositadamente, mas à uma complexa relação entre "Saber" e "Poder".

Por ser a memória uma construção coletiva, certamente, não bastaria que $O$ que é isso companheiro? fosse publicado para que essa versão se tornasse dominante. Foi preciso que suas representações fossem reeditadas e reforçadas continuamente pela publicação de outras obras, como as de frei Betto.

A produção historiográfica sobre o período não passou ilesa a esse esforço de construção da memória. Essa influência foi fortificada pela proximidade temporal com o período do regime militar e pelo fato de muitas das obras acadêmicas de referência terem sido escritas por historiadores que participaram das organizações de esquerda e até mesmo da luta armada. Essas peculiaridades impõem algumas limitações que precisam ser observadas com cuidado pelo pesquisador. Tomamos como exemplos dois estudos dedicados à análise da versão militar.

Aline Prado Atássio em sua dissertação de mestrado intitulada "A batalha pela memória: os militares e o golpe de 1964" procura analisar a construção da memória militar sobre o golpe de 1964, tomando como fonte a "Coleção História Oral do Exército. 1964: 31 de março - o movimento revolucionário e sua História", publicada pela Biblioteca do Exército editora (Bibliex) em 2003. 
Através da análise documental e pesquisa bibliográfica, a autora procura, no primeiro capítulo, compreender as raízes das estruturas de pensamento dos militares, analisando um a um os episódios na história brasileira pré-1964 em que os militares tiveram participação efetiva; e nos quais sua autoimagem foi construída (ATASSIO, 2007, p. 34). Nos capítulos posteriores, Atássio se atém à análise dos temas abordados pelos militares em suas entrevistas para a publicação. Ela procura salientar o caráter coletivo desta memória, sua seletividade, seu papel legitimador. (ATASSIO, 2007, p. 20).

Em vista disso, a autora conclui que a publicação por ela estudada cumpre a função de "História oficial, ou seja, a História que o exército como instituição deseja passada à sociedade e principalmente aos seus futuros oficiais" (ATASSIO, 2007, p. 178), nela se destaca a aspiração da instituição de que a história do golpe e do regime seja compreendida como a resposta atenta dos militares ao clamor da sociedade por uma intervenção em represália às ações da esquerda, que seria culpada inclusive pelos excessos da corporação; os quais, mesmo tendo sua existência admitida, não seriam suficientes para qualificar o governo liderado pelos militares como uma ditadura.

No artigo "A guerra da memória: a ditadura militar nos depoimentos de militantes e militares", assim como Atássio, João Roberto Martins Filho investiga uma série de depoimentos cedidos por altos oficiais das forças armadas; neste caso, a dos pesquisadores do CPDOC, que posteriormente foi publicada em livros. O autor opta por concentrar sua análise nas considerações dos depoentes sobre a prática da tortura durante o regime (MARTINS FILHO, 2003, p.8-9).

Atássio e Martins Filho compartilham a conclusão de que a construção da narrativa militar sobre o período foi um empreendimento em resposta à publicação contínua das reminiscências de ex-militantes de esquerda e à hegemonia exercida por essas versões no senso comum sobre da ditadura. Desta forma, os autores consagram a ideia de que se o combate das armas é findo, o da memória há de ser travado por um longo tempo; além de justificarem a perspectiva de análise historiográfica que reduz suas disputas à dicotomia "esquerda versus direita".

Certamente, a partir do momento em que essa disputa é constatada ela é considerada digna de ser trabalhada pela historiografia. No entanto, manter essa divisão cunhada pela própria memória pode esconder aspectos que a adoção de outra perspectiva é capaz de elucidar.

As categorias "ex-militantes" e "militares" não podem ser tomadas como representantes de blocos monolíticos. Permanecem divergências internas pela construção da 
memória que não podem ser negligenciadas. Mesmo a da esquerda sendo a principal concorrente da militar, dentro da própria corporação existem disputas que buscam justificar as atitudes tomadas, reafirmar a identidade de determinados grupos e posicionar-se em relação a outras demandas do presente.

\section{Escrita epistolar: projeto memorialístico}

A proposta de analisar o processo de construção memorialística utilizando como fontes as cartas da prisão de frei Betto enseja questionar a respeito da capacidade elucidativa que esse tipo de fonte possui, visto que a escrita epistolar - diferente de outras fontes - não tem no ato de lembrar a sua intencionalidade principal. Ela busca prioritariamente narrar o cotidiano. No entanto, as missivas do dominicano possuem peculiaridades que levam a crer que suas funções vão muito além daquelas mais recorrentes e que, portanto, constituem um precioso material para se compreender as tensões e disputas que envolveram a constituição de uma narrativa sobre o regime ditatorial que se instaurou no Brasil a partir de abril de 1964.

O primeiro argumento para que elas sejam vistas distintamente das produções do mesmo gênero é o fato de terem sido publicadas. O lançamento do livro "Dai Soterranei Della Storia", na Itália, em dezembro 1971, reunindo o conjunto daquelas que foram escritas nos dois primeiros anos de seu cárcere indica que mesmo que não fosse a intenção do religioso tornar sua correspondência pública, a partir de 1972, todas as missivas foram produzidas com a consciência de que eram enormes as possibilidades de serem publicadas, como no caso das primeiras.

Em segundo lugar, pelo fato de terem sido escritas e remetidas do interior de presídios em um período em que o país vivia sob um regime autoritário. Sendo assim, não existia qualquer garantia de que a correspondência dos detentos, principalmente a dos políticos, chegaria às mãos dos destinatários sem antes serem entregues aos serviços de informação do governo. A privacidade das missivas pode ser questionada com base em uma série de dados. O próprio autor registra em diversas cartas a ação da administração penitenciária ao censurar trechos de sua correspondência:

Até semana passada, em sete meses que estamos aqui, era o diretor que censurava nossas cartas, e podíamos remetê-las duas vezes por semana. Agora transferiu esse encargo para o serviço de censura da penitenciaria, que cuida da correspondência de todos os presos. Isso significa algumas restrições. A partir do dia 22 só poderemos enviar cartas uma vez por semana, e os envelopes de quem nos escreve devem ser devolvidos para o arquivo. Antes assinávamos recibo num livro e os envelopes ficavam em nosso poder. A correspondência que nos chega do exterior é enviada a S. Paulo, a $700 \mathrm{Km}$ daqui, para ser traduzida. Uma carta que recebi das monjas 
contemplativas de Blagnac, na França, deu entrada aqui em 25 de novembro; até agora não chegou as minhas mãos (BETTO, 2008, p.205).

Em outras cartas, o autor recomenda a seus interlocutores que mostrem suas correspondências a terceiros, o que reafirma a potencial publicidade a que foram submetidas.

Frei Betto, recorrentemente, afirma que suas cartas não foram produzidas com a intencionalidade de serem divulgadas. Todavia, o dado inequívoco sobre sua publicidade é a consciência expressa pelo autor de que elas poderiam chegar às mãos dos mais importantes personagens históricos, a exemplo do papa Paulo VI.

\begin{abstract}
"Não há dúvida de que Paulo VI está muito atento ao que vocês dizem. Há três semanas fui chamado a Secretaria de Estado. O adjunto mostrou-me duas folhas escritas pelo próprio papa: suas reflexões sobre as cartas do Betto. Ele as leu para mim. Muito edificante; apesar de todo seu trabalho, ele se debruçou longamente sobre estes textos". [...]

Isso não chega a me envaidecer, embora me sinta feliz por ver que essa provação não é inútil. Imagino o papa lendo as cartas, sinto a impressão de um diálogo intimo com ele. Vivendo na prisão, tenho certeza de um diálogo íntimo com a Igreja (BETTO, 2008, p. 150).
\end{abstract}

Isso justifica a abordagem de suas cartas em formato de publicação, em detrimento daquelas escritas e remetidas em sua plataforma original. Uma vez que, para o objetivo explanado, importa mais aquilo que o autor desejou que chegasse ao conhecimento do grande público do que o que foi preterido mediante o processo de edição para o suporte livresco.

Certamente, não é o fato das missivas de frei Betto terem um caráter público que as qualificam como fonte/objeto para a análise histórica da memória. É necessário que elas sejam vistas como parte de um projeto editorial mais amplo.

Desde o primeiro lançamento de suas cartas da prisão, ainda durante os anos de cárcere, o frade periodicamente dedica obras à construção de uma narrativa sobre a ditadura no Brasil. Pode-se dizer que, aproximadamente, a cada uma década suas publicações se voltam para o tema. Desse modo, é possível observar que, em comparação aos livros que as sucederam, as missivas da prisão se relacionam com a passagem do tempo e com o rememorar de maneira peculiar. Ao invés de se dedicarem exclusivamente a evocar o passado, seu esforço é demarcar uma posição sobre o que seria lembrado na posteridade. Por isso, podemos considerar que elas são o projeto inicial de um "edifício" memorialístico que seria realizado ao longo dos anos subsequentes.

Diante disso, a utilização desse material se justifica não só por contribuir, especificamente, para a compreensão da construção da memória sobre a ditadura militar no Brasil, mas, também por constituir um exemplo de variação possível das fontes utilizadas para 
se analisar esse tipo de discurso e, principalmente, por conta de seu processo de edificação não estar limitado a relacionar-se com o tempo de maneira retrospectiva.

Sendo a memória um empreendimento social, disputada politicamente, é preciso estar atento aos registros do seu planejamento para o futuro. Qualquer insatisfação com a maneira pela qual o passado é representado e divulgado revela, antes de tudo, uma preocupação com suas consequências políticas e culturais no porvir. Essa peculiaridade é explicitada mais intensamente quando se manifesta uma preocupação com a maneira como os fatos serão evocados. O que corrobora a ideia de que fontes como as cartas, mesmo dedicando-se a sugerir o que deverá ser lembrado no futuro, não deixam de ter valor para se compreender o passado.

A análise das fontes revela a existência de uma tensão entre as representações que começavam a despontar na imprensa diária e em outros meios, sobre a participação do grupo de dominicanos, do qual frei Betto fazia parte, na luta armada e especificamente no episódio do assassinato do líder da ALN, Carlos Marighella.

Em sua correspondência, o dominicano não se dedica a fazer muitas perguntas, estabelecendo assim diálogos contínuos. Talvez isso se deva à incerteza acerca de quanto tempo suas missivas levariam para chegar às mãos de seus interlocutores e, até mesmo, se de fato chegariam algum dia; o que se estende também ao recebimento das respostas. Portanto, ele disserta longamente sobre diversos temas como a rotina na prisão e a morosidade do processo judicial. No entanto, três temas se destacam como os mais profundos e extensos: a Igreja Católica, a ineficácia do sistema prisional e a cultura de massa.

Ao discorrer sobre esses temas de maneira quase despretensiosa, o autor revela um profundo desconforto com o modo como a participação dos dominicanos presos na luta armada era tratada na contemporaneidade por jornais e formadores de opinião, o que provavelmente definiria como elas seriam lembradas no futuro. Diante dessa "ameaça" frei Betto faz de suas cartas um verdadeiro manifesto endereçado aos grupos nos quais mais lhe interessava restaurar a imagem e memória do grupo de religiosos. São eles: a Igreja Católica, a sociedade brasileira (leia-se, a opinião pública) e, principalmente, a esquerda.

Em relação à Igreja Católica, a defesa dos dominicanos se inicia pelo ataque. O frade, ao invés de confessar sua preocupação com a memória que se construiria sobre os dominicanos presos, diversas vezes procura questionar as atitudes e omissões da instituição perante as suas prisões. Ou seja, em um futuro próximo, essa memória daria muito mais destaque à omissão dos bispos diante das arbitrariedades da ditadura, do que à ação de jovens religiosos que colaboraram com uma organização de luta armada. 
Quando tudo isso for contado no futuro, uma pergunta ficará: e a Igreja, não disse nada? Digo isso não para que venham em nossa defesa, mas porque é sua obrigação defender os direitos da pessoa humana, promover os pobres, combater as (riscado pela censura do presídio). Esta pergunta paira sobre a Alemanha, onde 6 milhões de judeus foram dizimados sem que "ninguém visse" (BETTO, 2008, p.52).

Frei Betto sabia que era enorme a desconfiança de parte da Igreja em relação aos dominicanos e severas as acusações de sua ala mais conservadora, as quais faziam coro àquelas promovidas pela imprensa diária. Assim, suas cartas procuram afirmar que, ao contrário do que apregoavam os grandes meios de comunicação, os religiosos não eram terroristas, mas cristãos que, em sua visão, assumiram radicalmente a opção pelos pobres.

\footnotetext{
Ontem dom Agnelo Rossi deu entrevista ao Estadão, na qual afirma que a nossa atitude nada teve a ver com o cristianismo. Disse que não fomos presos nem confessando, nem comungando... como se o cristianismo fosse apenas confessar e comungar - coisa, aliás, que jesus não fez, e ainda acrescentou que "nem todo aquele que diz 'senhor, senhor' entrará no reino dos céus” (BETTO, 2008, p.50).
}

A estratégia assumida pelo autor para dotar de legitimidade as opções dos dominicanos conduz a discussão de um aspecto prático que colocava em questão a participação de membros da Igreja na política nacional, chegando a apoiar a violência revolucionária, para um aspecto teórico que questiona o papel da Igreja na sociedade e a sua importância na promoção da justiça social na história da salvação.

Em suas cartas, o dominicano defende a tese de que a Igreja Católica passava por um processo de transformação que, embora lento, já dava seus frutos e era irreversível. Desse modo, ele procura filiar a visão que professa sobre o papel da instituição na sociedade e o processo soteriológico à essa nova visão do cristianismo que teria surgido com o Concílio Vaticano II, em 1962.

A renovação pela qual a Igreja passava não deixava, em sua perspectiva, de gerar o embate entre visões distintas do cristianismo. Para o autor, aquela, anterior ao concílio e marcada pelo triunfalismo clerical, seria incapaz de compreender esse novo entendimento do papel da instituição na sociedade, ao qual os dominicanos se perfilhavam.

Assim, a demonstração da existência desse embate deixaria claro o quanto a incompreensão e a ignorância seriam a verdadeira razão das acusações explícitas ou veladas de que os dominicanos presos não passavam de comunistas que se infiltraram na Igreja para arregimentar quadros. Para o autor, a gravidade dessas denúncias era reforçada pelos jornais e agentes da ditadura que não cessavam de questionar se as atitudes do grupo permitiriam que ainda fossem considerados cristãos e, principalmente, membros da Igreja Católica. 
Em carta à família o autor afirma:

\begin{abstract}
De fato, havia uma interpretação ideológica do cristianismo feita pelos poderosos. E a ordem social, que tem abusos na sua própria essência, encontrou nessa interpretação a sua justificativa. (...) um bispo como dom Sigaud pode afirmar, sem risco de ser considerado herético, que a ordem social, dividida em ricos e pobres, provem da vontade divina que não quer todos os homens iguais...

Agora, na época pós-conciliar, estamos em fase de reformização (volta às fontes). Vemos claramente que o cristianismo não se identifica com nenhuma ordem social; o cristianismo desafia e contesta todas elas. (...). Vejo com otimismo a renovação da Igreja (BETTO, 2008, p.44).
\end{abstract}

Outro artifício evocado para dar legitimidade aos dominicanos presos, independentemente da consciência do autor ao utilizá-lo, é a recorrente alusão à figura de Jesus como um perseguido político que se constitui como paradigma inaugural do papel contestatório que o Cristianismo deveria assumir diante das injustiças dos poderes constituídos.

Em carta a uma amiga, o frade afirma:

Ontem os jornais publicaram nota oficial do governo; afirma que no Brasil não existem presos políticos, só bandidos. Veja a que fui promovido! Bandido para o Estado e frade para a Igreja. Mas cristo não foi crucificado como marginal ao lado de dois ladrões? Portanto, para nós a piada não é nova (BETTO, 2008, p.43).

A perseguição, prisão e condenação à morde de Jesus seria a prova mais contundente de que, estando presos, os dominicanos dariam testemunho de que seguiam fielmente o projeto salvífico de Cristo. Viver como pobres ao lado dos pobres e padecer pela justiça seriam demandas da renovação atravessada pela Igreja.

Apesar do talento literário com que o autor defendia as causas que o levaram à prisão, e sua certeza quanto a sua nobreza, em sentido prático era necessário deixar evidente para as alas conservadoras da Igreja, para a sociedade e, mais do que tudo, para a posteridade que os dominicanos eram apoiados por importantes membros da hierarquia católica. Isso fica claro ao se observar o registro do nome completo de todos os bispos, padres e membros de ordens religiosas que os visitaram na prisão. Aqueles que lá estiveram mais de uma vez têm seus nomes repetidos por completo. Entre eles, se destacam os nomes de: Dom Vicente Scherer ${ }^{2}$, Dom Agnelo Rossi ${ }^{3}$, Dom Umberto Mazzoni ${ }^{4}$, Dom Avelar Brandão, Dom Tomás Bauduíno $^{6}$, Dom Paulo Evaristo Arns ${ }^{7}$, Dom José Gonçalves da Costa ${ }^{8}$, Dom Lucas Moreira Neves ${ }^{9}$; também pelos representantes da Ordem dos Frades Pregadores: padre Vincent de Couesnongle $^{10}$, padre Aniceto Fernande ${ }^{11}$ e frei Domingos Maia Leite ${ }^{12}$.

Não obstante, o mais importante gesto de apoio veio do Vaticano. Os representantes da ordem religiosa transmitiram aos prisioneiros, em suas visitas e pelas correspondências, a 
certeza de que Paulo VI tinha ciência da situação em que se encontravam os dominicanos brasileiros; de que recebera a carta enviada pelos prisioneiros, e ainda, que escreveu uma reflexão acerca das cartas de frei Betto (BETTO, 2008, p.150). O apoio do papa era, para o autor, o atestado mais importante de legitimidade de suas opções.

Outra preocupação do frade é a opinião pública sobre os dominicanos, visto que ela era profundamente influenciada pela imprensa que os qualificava como terroristas. Assim como em relação à Igreja, o autor procura denunciar a passividade da sociedade civil, questionando como essa atitude seria lembrada no futuro.

Nesse sentido, diversas vezes o autor compara a indiferença da sociedade brasileira diante das arbitrariedades do regime que se instaurou com o golpe de 1964 com a postura da sociedade alemã diante dos crimes do regime nazista. Com essa analogia, ele procura deixar patente a afirmação de que os dominicanos são vítimas do regime autoritário, e não inimigos do país, como queriam fazer crer as autoridades que os mantinha presos.

\begin{abstract}
Em pequenas aldeias do interior da Alemanha, durante a última guerra, as donas-decasa reclamavam da fuligem expelida pelas chaminés das "fabricas" nazistas. Ninguém via nada, o único sinal era a fuligem. Derrotado o nazismo, o mundo soube que aquelas "fabricas" eram campos de extermínio de judeus e comunistas. Tarde demais. A fuligem desaparecera, as vítimas também. O Vigário permaneceu calado (BETTO, 2008, p.48).
\end{abstract}

Apesar da legitimidade perante a Igreja ser algo importantíssimo para os dominicanos por serem seus membros ativos, e mais ainda por participarem de uma ordem religiosa, o fator que mais instiga a reflexão de frei Betto em sua correspondência é a desconfiança da esquerda em relação aos dominicanos.

Essa desconfiança já se alimentava pela tradicional postura da Igreja Católica no Brasil de legitimadora do status quo. Assim, a participação de seus membros em movimentos contestatórios era vista com apreensão por muitos militantes.

Essa desconfiança se aguçou ainda mais após o episódio trágico da emboscada que resultou no assassinato de Carlos Marighella. Como já foi mencionado anteriormente, isso resultou em uma discussão entre frei Betto e o historiador Jacob Gorender sobre os meios que teriam levado o DEOPS de São Paulo a rastrear o guerrilheiro baiano.

Frei Betto defende a tese de que a CIA (Agência central de inteligência dos Estados Unidos), por meio de agentes infiltrados na ALN e grampos telefônicos instalados nos locais ligados aos dominicanos, foi a responsável por rastrear o paradeiro de Carlos Marighella e entregar à ditadura brasileira as informações necessárias para que preparassem a emboscada na qual o líder comunista seria assassinado (BETTO, 1982, 141-186). Em sua obra célebre 
Combate nas Trevas, Jacob Gorender atribui a obtenção dessas informações às sessões de tortura a que frei Fernando de Brito e Ivo Lesbaupin foram submetidos pelo DEOPs de São Paulo (GORENDER, 1987, p. 171-179).

Em sua biografia Marighella: o guerrilheiro que incendiou o mundo, Mário Magalhães afirma que uma das "ilusões capitais" alimentadas pelo líder comunista em seus escritos foi "associar a resistência à tortura meramente a uma escolha. Como se fosse possível isolar a mente sã do corpo flagelado" (MAGALHÃES, 2012, p.536).

Citando escritos de Marighella, Magalhães demonstra que o líder comunista define a entrega de informações mediante tortura como uma prova da inadequação e até mesmo de indignidade do militante diante da causa revolucionária:

No opúsculo se fores preso, camarada... (1951), ele sustentou: a polícia tem consciência de que as "torturas físicas", "por piores que sejam, não são capazes de dobrar a vontade de um militante digno". Marighella relaciona confissões extirpadas a ferro e fogo à traição, como se a responsabilidade pelas informações obtidas não fosse do torturador e do Estado do qual é funcionário: "não há torturas que façam um militante revolucionário trair seus camaradas" (MAGALHÃES, 2012, p. 536).

Portanto, para os dominicanos havia o risco de figurarem na memória da esquerda como fracos e traidores. Por conta daqueles que não aguentaram e colocaram a perder o projeto da revolução. Diante disso, narrar o sofrimento dos religiosos na prisão se tornou, para frei Betto, a melhor estratégia para que, mesmo que não pudesse mudar a concepção da esquerda sobre a não resistência à tortura, fosse capaz de demostrar que eles eram verdadeiramente identificados com o grupo daqueles que lutavam contra a ditadura e eram cruelmente perseguidos por seus agentes, além de sofrerem na prisão e no pau-de-arara os mesmos males que todos os outros presos políticos.

Assim, Frei Betto faz de suas missivas um verdadeiro manifesto em defesa da dignidade dos dominicanos. Para isso, ele procura repetidamente alguns exemplos dessa condição.

Um dos muitos detalhes curiosos da correspondência de frei Betto, que podem passar despercebidos, é o fato de inúmeras vezes os nomes de companheiros de cela serem mencionados por completo, inclusive dos confrades dominicanos. Mesmo em cartas endereçadas aos familiares que, portanto, conheciam bem os amigos do autor, os nomes completos são utilizados. Esse detalhe indica a consciência de que as missivas poderiam se tornar públicas, e que serviriam como um registro quase formal do sofrimento dos religiosos. 
Ao longo dos quatro anos de correspondência, o autor insiste no registro das péssimas condições da prisão na morosidade do processo no desrespeito a direitos básicos dos presos, além de fazer referência às sucessivas transferências injustificadas.

Em carta a uma religiosa, ele afirma:

Na última quinta, nos mandaram pra cá, próximo $30 \mathrm{~km}$ do Mato Grosso, distante $640 \mathrm{Km}$ de São Paulo - onde temos família e advogado. Parece pesadelo tudo isso; como se alguém brincasse com vidas humanas, tornando-as joguetes de seus caprichos. (BETTO, 2008, p.142)

Protestando contra a precariedade e as arbitrariedades dessas condições, o grupo de presos políticos que se formou, principalmente, no presídio Tiradentes na capital paulista, empreendeu em 12 de maio de 1972 uma greve de fome. Para o dominicano, essa é uma das mais importantes provas da grandeza moral de seus companheiros. Era a chance de demonstrar a resiliência e fidelidade dos religiosos aos outros companheiros presos:

Ontem, às 18 horas, terminou a nossa greve de fome, que durou 33 dias nessa segunda fase, e seis na primeira, um total de 39 dias - provavelmente a mais longa de que se tem notícia no Brasil. Entre os 36 presos políticos que participaram não houve nenhuma defecção, todos firmes até o fim. (BETTO, 2008, p.153)

A perda da liberdade não acarreta necessariamente a perda da dignidade. Por isso não me dobro às injustiças dentro da cadeia. Há presos, infelizmente, que tudo aceitam, como se fossem surdos e cegos. Para estes importa apenas uma coisa: recuperar a liberdade física, a qualquer preço. Não sou desses. Agir assim seria a minha destruição moral. Mesmo que aquela greve de fome venha a significar a perda da liberdade condicional, não me importo. (BETTO, 2008, p.139).

Apesar da importância que frei Betto atribuiu aos exemplos supracitados, dois são tomados como os mais emblemáticos do sofrimento dos religiosos presos. Em primeiro lugar, as torturas sofridas pelo seu confrade Tito de Alencar Lima, na Operação Bandeirantes:

Em carta a uma amiga, o frade afirma:

Ele estava bem, alegre, tranquilo, recuperado do que havia sofrido no DEOPS. Bem como todos nós, livres da fase de interrogatórios. Pouco implicado, aguardava o momento de o colocarem em liberdade. Mas veio o DOI-CODI e o levou. Isso há pouco mais de uma semana (...). Hoje, soubemos que frei Tito de Alencar Lima "tentou suicídio" no DOI-CODI... Levado ao Hospital Militar, recebeu transfusões de sangue, mas continua incomunicável. (BETTO, 2008, P.22).

$\mathrm{O}$ autor faz questão de ressaltar o orgulho com que frei Tito narrava o fato de ter resistido à tortura, não entregando, assim, qualquer informação aos agentes da repressão:

Tito já se encontra conosco. Acamado, manca, recupera-se dos sofrimentos recebidos. A intensão do exército era interrogar de novo todos os dominicanos; considerava que nossos depoimentos no DEOPS haviam sido colhidos a toque de 
caixa. Agora Tito está bem, com o moral altíssimo. Todos que resistem ficam com o moral bem alto. (BETTO, 2008, p.25)

Em segundo lugar, o autor sublinha o fato de que os dominicanos, juntamente de alguns outros presos políticos tiveram seus direitos políticos cassados, passando assim à condição de presos comuns, tendo sido integrados à população carcerária, perdendo qualquer direito que os distinguissem dos muitos assassinos, estupradores e ladrões que ali cumpriam pena. (BETTO, 2008, p.161)

Por não ser um fato usual na história do Brasil, a passagem de um "preso político" para a condição de "preso comum" é interpretada, pelo autor, como algo que distingue os religiosos dos outros perseguidos:

De um lado, recebo com profundo espirito de fé esta oportunidade de solidarizar-me na carne aos "condenados da Terra". De outro, sei da responsabilidade histórica que pesa sobre os nossos ombros; a conquista do direito de prisão especial ao preso político é fruto de muita luta e incontáveis sacrifícios. O futuro indagará quem foram os primeiros obrigados, no Brasil, a anular essa conquista consagrada hoje pelo direito internacional. (BETTO, 2008, p.159)

Passar à condição de preso comum significava a perda de qualquer garantia, inclusive de segurança. Facilmente, a repressão poderia incumbir um preso qualquer de eliminar um deles. Para o frade, o julgo de uma arbitrariedade adicional era um sofrimento a mais que não poderia ser desconsiderado pela opinião pública, para que assim, na memória sobre o período o "martírio" dos dominicanos lhes rendesse ao menos, o benefício da dúvida, diante das acusações de fraqueza e traição.

Assim, o que se pretende é que o trabalho junto à obra de frei Betto contribua para a compreensão do processo de solidificação da chamada "memória dos vencidos" e que, mais do que isso, demonstre as disputas políticas que permearam esse itinerário, não apenas entre militares e militantes, mas, também, entre aqueles que integravam um mesmo polo identificado como "esquerda".

\section{Conclusão}

A análise do processo de construção da memória da ditadura militar brasileira utilizando como fontes documentos produzidos contemporaneamente ao regime, os quais buscam, na atualidade, rememorar e significar fatos ocorridos nas prisões e, portanto, em espaços restritos e encobertos pelo próprio regime, visa demonstrar o quanto esse material pode oferecer subsídios para a compreensão das disputas que envolvem a memória sobre o período. 
O trabalho com essas fontes permite observar que a relação que o indivíduo que narra o passado estabelece com o tempo não se restringe a uma visão retrospectiva. Esse tipo de fonte evidencia, portanto, que as tensões e disputas do presente podem ensejar e produzir as bases de sustentação de um projeto memorialístico que pode e provavelmente será executado na posteridade.

No caso específico de frei Betto, as suas cartas da prisão baseando-se nas opiniões que paulatinamente ganhavam força e eram expressas nos grupos sociais dos quais o dominicano fazia parte, como a Igreja Católica e a Esquerda brasileira (apesar da sua multiplicidade de organizações), antecipam e projetam uma disputa em torno da memória da resistência à ditadura militar brasileira.

A análise dessas missivas, compiladas em Cartas da Prisão: 1969-1973, demonstra uma constante preocupação por parte do autor, ainda que não se possa determinar que ela seja manifestada de maneira consciente, de que, caso não houvesse qualquer tipo de pronunciamento por parte do grupo dos dominicanos ligados a ALN, aqueles que estavam presos figurassem na memória da Igreja como comunistas que se infiltraram nos grupos de jovens para conquistar corações e mentes; pela sociedade brasileira seriam lembrados apenas como terroristas punidos com justiça por seus atentados à ordem estabelecida, e entre os militantes de esquerda ficariam estigmatizados como a ala mais fraca da luta armada que, desprovida da resiliência necessária para assumir o compromisso com a revolução brasileira, os traiu ao não resistir às sevícias a que foi submetida; o que fatalmente teria resultado no rastreamento e assassinato do mais admirado líder da guerrilha urbana no Brasil, Carlos Marighella. Assim, reafirma-se a importância das cartas da prisão dos frades dominicanos como uma peça impreterível para se compreender seu projeto memorialístico que vem sido cultivado desde sua libertação em outubro de 1973.

\section{Notas:}

\footnotetext{
${ }^{1}$ Pollak narra que ao entrar em contato com um grupo de mulheres sobreviventes de Auschwitz-Birkenau para realizar entrevistas, a responsável da instituição fez uma seleção das testemunhas. Ou seja, buscava-se um controle do que seria lembrado e registrado, de maneira que a memória desejada fosse reforçada e pontos de dissenso fossem silenciados ou esquecidos. (POLLAK, 1989, p.10).

${ }^{2}$ Cardeal, Arcebispo de Porto Alegre, RS (1947-1981).

${ }^{3}$ Cardeal, Arcebispo de São Paulo, SP (1965-1970).

${ }^{4}$ Núncio apostólico (1969- 1973).

${ }^{5}$ Cardeal, Arcebispo de Salvador, BA (1971-1986).

${ }^{6}$ Bispo de Goiás (1967-1998).

${ }^{7}$ Arcebispo metropolitano de São Paulo, SP (1970-1998).
} 


\footnotetext{
${ }^{8}$ Bispo da diocese de Presidente Prudente, SP (1969-75); a qual pertence à cidade de Presidente Venceslau-SP, onde frei Betto cumpriu a última parte de sua pena.

${ }^{9}$ Bispo-auxiliar de São Paulo, SP (1967-1974).

${ }^{10}$ Representante do mestre da Ordem dos Frades Pregadores.

${ }^{11}$ Mestre Geral da Ordem dos Frades Pregadores.

${ }^{12}$ Superior dos Dominicanos no Brasil.
}

\section{Fontes:}

BETTO, Frei. Cartas da prisão 1969-1973. Rio de Janeiro: Agir, 2008.

\section{Referências Bibliográficas}

AARÃO REIS, Daniel (Org.). Versões e Ficções: O seqüestro da História. São Paulo: Editora fundação Perceu Abramo, 1997.

ATASSIO, Aline Prado. A batalha pela memória: os militares e o golpe de 1964. Dissertação de Mestrado, Ciências Sociais, Departamento de Ciências Sociais, Universidade Federal de São Carlos, 2007.

BETTO, Frei. Batismo de Sangue - A luta clandestina contra a ditadura militar - Dossiês Carlos Marighela \& Frei Tito. 14 edição. Rio de Janeiro: Editora Rocco, 2009.

Batismo de Sangue: Os dominicanos e a morte de Carlos Marighella. Rio de Janeiro: Civilização Brasileira, 1982.

BOURDIEU, Pierre. A Ilusão Biográfica. In: MORAES, Marieta da M.; AMADO, Janaína. (Orgs). Usos e abusos da História oral. 2. ed. Rio de Janeiro: Fundação Getúlio Vargas, 2000.

FOUCAULT, Michel. Microfísica do Poder. Tradução Roberto Machado. 2. Ed. Rio de Janeiro: Paz e Terra, 2015.

GORENDER, Jacob. Combate nas trevas. A esquerda brasileira: das ilusões perdias à luta armada. 2. Ed. São Paulo: Editora Àtica, 1987.

HALBWACHS, Maurice. A memória coletiva. Tradução Beatriz Sidou. São Paulo: Centauro, 2003.

LE GOFF, Jacques. História e Memória. Tradução Bernardo Leitão. Campinas: Editora da UNICAMP, 1990.

MAGALHÃ̃ES, Mario. Marighella: o guerrilheiro que incendiou o mundo. 5. reimpr. São Paulo: Companhia das letras, 2012.

MARTINS FILHO, João Roberto A guerra da memória: a ditadura militar nos depoimentos de militantes e militares. In: XXIV Congresso Internacional da Associação de Estudos Latino-Americanos, 2003, Dallas TX. Disponível em: $<$ http://lasa.international.pitt.edu/Lasa2003/FilhoJoaoRobertoMartins.pdf $>$. Acessado em: 26 jul. 2015.

NORA, Pierre. Entre Memória e História: a problemática dos lugares. Projeto História. São Paulo: PUC-SP. n. 10, 1993, p.7-28.

POLLAK, Michael. Memória e Identidade Social. Estudos Históricos. Rio de Janeiro: vol. 5, n.10, 1992, p.200-2012. 1989, p. 3-15.

Memória, esquecimento, silêncio. Estudos Históricos. Rio de Janeiro: vol. 2, n.3, ROLLEMBERG, Denise. As Trincheiras da Memória. A Associação Brasileira de Imprensa e a ditadura (1964-1974). In: QUADRAT, Samantha Viz; (Orgs.). A construção 
social dos regimes autoritários. Legitimidade, consenso e consentimento no Século XX. Vol. 2: Brasil e América Latina. Rio de Janeiro: Civilização Brasileira, 2010.

. Carlos Marighella e Carlos Lamarca: memórias de dois revolucionários. In: FERREIRA, Jorge; AARÃO REIS, Daniel (orgs.). As esquerdas no Brasil. Revolução e democracia. Vol. 3. Rio de Janeiro: Civilização Brasileira, 2007.

Esquecimento das memórias. João Roberto Martins Filho (org.). O golpe de 1964 e o regime militar. São Carlos: EDUFSCar, 2006. 